\title{
Reforming senates in the post-revolutionary North Atlantic world
}

\section{An introduction}

\section{Nikolaj Bijleveld and Wybren Verstegen}

\section{Introduction}

The rationale for connecting the historiography of the senates in small European countries and Canada against the background of the major powers in the North Atlantic is illustrated in a quote from George Brown, one of the architects of Canadian bicameralism, from 1865:

\begin{abstract}
We are striving to do peacefully what Holland and Belgium, after years of strife, were unable to accomplish. We are seeking by calm discussion to settle questions that Austria and Hungary, that Denmark and Germany, that Russia and Poland, could only crush by the iron heel, or armed force. We are seeking to do without foreign intervention that which deluged in blood the sunny plains of Italy. We are striving to settle forever issues hardly less momentous than those that have rent the neighbouring republic and are now exposing it to all the horrors of civil war.
\end{abstract}

(Ajzenstat et al. 2003)

During the American Civil War (1861-1865), Canadian politicians worked under severe political pressure from Westminster to give their country a constitution that would keep this British colony, with its population from French and English descent, together. They knew how ethnic, religious and linguistic divisions, as well as nationalistic sentiment, could easily tear states apart.

In the nineteenth century, small powers all over the North Atlantic faced similar risks, problems and threats. Denmark had a German-speaking minority that aimed for secession. The United Kingdom of the Netherlands was divided by linguistic and religious barriers that split the country into two states after the revolutionary year, 1830. In Ireland, religious differences continue to divide the country to this day. In Canada, one of the most important building-blocks of the new constitution and the proposed solution to this division - was the creation of a senate, with senators to be appointed by the Crown (the governor-general). It gave and still gives power to and could and still can prevent legislation that harms the country's French-speaking minority (Cardinal, this volume; Smith, D. E., this volume).

In the countries scrutinised in this volume - Belgium, Canada, Denmark, Finland, Ireland, Norway, Sweden and the Netherlands - senates were always 
formed under the more or less explicit supervision of the great powers or at least in the knowledge that powerful neighbours might interfere in domestic affairs, be it France, Great Britain, Germany, Russia, the United States or the dwindling might of Sweden in the case of Norway (Smith, E., this volume). A good example is the Belgian Senate, created after the revolution of 1830 as an answer to the English and French concerns about the potentially radical character of the new state (Stengers 1995). This, however, was not the only way in which the existence of strong neighbours influenced constitutional thinking in small nation-states. In Canada and the Netherlands, for instance, constitutions, including their senatorial provisions, were even seen as a way of making nations stronger, i.e. less vulnerable to aggressive and powerful neighbours (Boyko 2014; Drentje 1998).

The senates selected for this volume share a vulnerability vis à vis the great powers, which distinguish them from the often-analysed and more famous upper chambers, such as the American or French Senates or the British House of Lords, which are still overrepresented in the literature (Schnatterer 2015). Furthermore, the countries in this volume share a common heritage with respect both to the Age of Revolution and to upcoming nationalism in the nineteenth century. Moreover, they also looked to each other when formulating their constitutions or even when deciding which role the senate should play, as the quote from George Brown illustrates. In all these small powers, senates were criticised every now and again and would frequently come under attack. In some cases, they were faced with the threat of abolition or were even abolished altogether, especially over the course of the twentieth century. Finally, all these senates seem to have gone through a process that reveals a lot of commonalities in the way they functioned and were reformed and discussed.

In the nineteenth century, bicameralism appeared to be the norm for nation states that were gradually transferring away from the traditional division of power between a monarch and estates to more democratic forms that left room for a novel idea - representation of 'the people'. This could lead to constitutions without (proper) senates, as in Norway (Smith, E., this volume) and Finland (Pekonen, this volume), or to a gradual disappearance of the senate, as in Sweden (Nergelius, this volume) and Denmark (Skjæveland, this volume). In that respect, the Nordic countries have a special reputation: in all these very stable democracies, senates either never existed or were abolished. Examining these nations together helps explain the paternity, transformation and relevance of the senates as legislative institutions over time.

All senates involved in this study differ considerably from each other, and there is no suggestion that they will come to resemble each other in the future. This is not due to the constitution-makers in these countries operating in isolation. Of course, they worked within their own political context, which generated different compromises in different circumstances (Drentje 2004), but they were certainly acquainted with the ideas, practices and usefulness of examples in neighbouring countries. Norway, for instance, was inspired by the Dutch Batavian Republic (Smith, E., this volume); the revolutionary Sister Republics of France looked at the United States and France itself for inspiration (Oddens, this volume); and 
Finland copied ideas from its Scandinavian neighbours (Pekonen, this volume). The outcome of the complex processes of making and remaking (but seldom imitating) constitutions was that senators could be appointed or chosen (1) by a large or small constituency, (2) at a central or at a regional level and (3) by the rich, the experienced or the better educated. They could be chosen directly or indirectly, with complicated voting systems, partly by special interest groups or by the same people who held a vote for the people's assembly. While the people's assemblies tended to resemble each other because of, for example, democratic ideals, universal suffrage, party politics etc., the senates discussed in this volume differ profoundly in terms of how they were constructed, how they operated and how politicians were admitted to the chambers (Riescher 2010).

\section{The roles of the senates}

From a historical perspective, we see how, in the nineteenth century, these countries struggled with the transition from the old political regime with a privileged position for elites to a new and more democratic system. Exactly how this compromise became manifest in the senate and the extent to which the senators remained in power depended heavily on the specific circumstances in which the senates were established. These were influenced by specific national ideas, revolutionary pressure, pressure from major neighbouring countries, social tensions, war etc. Bicameralism appears to have been a generally acceptable solution. A lower house would offer 'the people' power, while the senate would ensure that the old elites (nobility and sometimes the clergy and landed elites) or previously independent federal states maintained some of their influence in the new political system. Especially in the nineteenth century, as Els Witte stresses (this volume), individuals were more important than their mandates. As a result and sometimes quite literally, as in the cases of Denmark (Christiansen, this volume) and the Netherlands (Van den Braak, this volume; Witte, this volume), senates were born from or maintained because of the compromise between progressive and conservative forces.

Even though the senate came to represent the old powers, one must not make the mistake of interpreting the senate as a classical element that would inevitably disappear from the new political parliamentary system. Envisioning bicameralism as the result of a compromise makes even more sense when looking at the role the upper house was expected to play in the nineteenth century. The newly formed senates played - or were supposed to play - an important role in stabilising the political situation in their country. In all cases, they served to assure that parliaments would think twice before putting new legislation into practice. Originally, even this common idea of what bicameralism was did not exist. In the Revolutionary Age, which influenced the political framework of the whole Atlantic World (Israel 2017), the idea of installing two councils, one of which was often called a senate, did not necessarily result in bicameralism. In some cases, the senate was the legislature that proposed laws, and the other council possessed limited power and was not seen as being connected to the senate or even as part of the legislative edifice in the first place (Oddens, this volume). 
In a time when countries in the Western world were gradually becoming more democratic, senates gained more prominence as chambres de réflexion to counter overly revolutionary or centripetal tendencies. Under parliamentarism, 'majority rule', so was the idea, needed a countervailing power. In practice, this also meant that the requirements for senators differed from those for the people's representatives, though these differences tended to diminish over time - for example, how they were elected (the franchise) or appointed. A move towards radicalism is, however, not the only danger of majority rule. Majority rule sometimes necessitates the protection of the interests of minorities or social groups. This became one of the functions of the Senate in Ireland (Dorney, this volume; O'Donoghue, this volume) and was especially successful in Canada (Cardinal, this volume). Senates in other countries, such as the Netherlands and Denmark (Christiansen, this volume), did not take up such a role, even though these countries had significant religious and ethnic minorities. In the Netherlands, religious parties opted for a broader representation of the population in the Senate but not necessarily for their fellow brethren, which solved the issue of minority representation in a different way (Van den Braak, this volume). Federal Canada is a union despite its internal differences and gave room to a linguistic minority and, gradually, to other (ethnic) minorities. The newly established unitary nation states in Europe, however, aimed to unify their citizens under one nation, which interfered with the representation of linguistic, religious and ethnic minorities.

The attempts to abolish senates proved to be a long, capricious and sometimes futile processes. In Denmark, the first attempt failed after the issue was entangled in other political discussions (Skjæveland, this volume). A second attempt succeeded because the issue was linked to matters concerning the future of the monarchy. Senates in each country encountered opposition. With the increasing emancipation of the people, they were accused more and more often of being conservative and sometimes even undemocratic. This accusation persisted, even though senates - because of the impact of democratic ideas concerning representation, franchise and eligibility - gradually came to resemble the lower houses in terms of social composition. In and of itself, this critique was obviously not enough, since many of the countries in this volume still have a functioning senate to this day. Path dependency, i.e. the way senates are integrated in the state system, the criteria for constitutional changes or the extent to which they differ from the lower house appears to explain why abolition can be so difficult to realise. In non-federal states, the old elites lost their power over time, as democratic principles became more widely accepted. If a senate did not succeed in reforming itself sufficiently, it might become outdated or redundant. Abolition could be sped up when the constitution was organised in a way that made fundamental changes relatively easy (Nergelius, this volume).

Both the upper house's ability to be adjusted to meet critique and its opportunities to reform and reinvent itself are closely related and highly relevant in the history of the senates. Senates could reform themselves based on the presupposition that parliament should not make 'hasty' decisions. From the nineteenth century onwards, senates used their position as a chambre de réflexion to check the 
quality of laws accepted by the people's assembly - for example, what occurred in the Netherlands. Here, the Senate examined whether new laws were in line with existing legislation, whether a new law might generate unforeseen consequences and whether a new law was to be considered just in the light of certain principles (Van den Braak, this volume). This function explains not only why but also how a 'second' chamber of 'sober thought' was formed in the cases of the Batavian Republic (Oddens, this volume) and Norway (Smith, E., this volume) by means of selecting certain members from a unicameral parliament to formulate a second opinion. The persisting desire to prevent hasty decisions may explain why, after the abolition of a senate, some of its original functions reappear in another guise, as Asbjørn Skjæveland (this volume) and Eivind Smith (this volume) illustrate for Denmark and Norway (cf. Riescher 2010).

'Thinking twice', however, does not mean that senates played a conservative role from the outset. Senates do more than block or delay laws accepted by the lower chamber or promote the interests of the elites. As studies about upper chambers show, their role can be far more fruitful: a senate can foster reconciliation in transitional phases (Baturo \& Elgie 2018; Nilsson, this volume), prevent disintegration (as in Canada), promote consistency in legislation (as in the Netherlands), mollify opposition from conservative elites and put a break on overly rash decisions made by the people's chamber (Verstegen, this volume). This stabilising aspect should not, however, be stressed too much. Most of the countries under scrutiny in this volume have been stable democracies for a long time. Though created to give stability to parliamentary systems, senates as such, it appears, can be useful, but they are not always a sine qua non for this stability, as the Nordic countries show.

\section{Structure and themes of this volume}

Eighteen case studies have been brought together in this book. Despite the vast variety in appearances of the senates and the multidisciplinary character of this volume, we can identify clear commonalities between the senates, often related to specific historical periods. Without pretending to offer an exhaustive list of issues covered by the authors and without using our periodisation as a straitjacket, we have ordered this volume thematically and chronologically in three parts. Since comparable developments in different nations do not always happen simultaneously, there are a few cases for which our thematic approach does not overlap with the suggested periods. Finally, it is important to realise that the chapters offer many more valuable insights than we can introduce here.

The first part, The need for a senate, concerns the way in which countries discussed and positioned the senate between the executive - either the monarch or the (revolutionary) government - and the people's assembly. This is roughly the period between Thermidor (1794), when France and its Sister Republics introduced senates as a reaction to the Jacobinism of the earlier period (Oddens, this volume), and the revolutions and upheavals of 1830 (Witte, this volume), 1837 (in Canada, Ducharme 2010) or 1848 (in Europe), which led to important reshuffles 
in the position of senates in many European countries. In this period, many countries decided to install a senate, but which exact role it would play was not yet clear. Oddens (this volume) illustrates that, during the Age of Revolution, the role of the senate was not related to bicameralism as it is today. Another example is Norway, which rejected a bicameral system but nevertheless decided to install a pseudo-senate (Smith, E. this volume) - possibly because it needed such a body or because bicameralism was seen as a sign of national maturity (quoted in Smith, D. E., this volume). The case of Denmark shows how nationalistic sentiments, the pressure of a war and the impact of revolutionary thoughts contributed to all parties agreeing with quite a liberal Senate (Christiansen, this volume).

All nations treated in this study share a revolutionary past, and all felt the need to discuss the installation of a senate. Especially in this period, the role of the major, powerful neighbours was of significant importance. During the American Revolution and after the downfall of Napoleon, revolutionary threats were feared equally by minor powers and the major powers surrounding them. In many of Europe's new monarchies in the early nineteenth century, senates were originally envisioned as a 'bulwarks' protecting the crown against revolutionary tendencies. This function makes clear that the Weberian idea of parliament as 'a counterforce, a representation of those ruled by the administration' does not always hold (Palonen 2019). During the Restoration and after the Revolution of 1830, most of the small states in Northern and Western Europe saw political reform under the watchful eye of the major powers that surrounded them, and they often depended on these nations. In 1813, the Netherlands became a new monarchy, followed by Belgium in 1830, and both countries installed a senate (Witte, this volume). Sweden chose the parvenu Bernadotte as its king in 1818. Finland was torn loose from Sweden in 1809, and the Russian tsar became, from the Finnish point of view, a new monarch. Even Ireland, as MacCartheigh and Martin (this volume) remind us, was in an entirely new political situation after the failed rebellion and French intervention of 1798. The country lost its own Parliament after the Act of Union with Great Britain in 1800 .

Once established, we see that senates periodically encountered crises related to wars, nationalist movements and the call for democratisation, which would later force the houses to legitimise and reform their role and function. This becomes clear in the second part of this volume, titled Democracy, the people and the senate, which primarily covers the period after the Revolution of 1848 and the 1860s until well into the early twentieth century, when nationalism and universal suffrage threatened or disrupted the existing order. Ultimately, these processes led to the Canadian federal constitution of 1867 (Smith, D. E., this volume) and to the installation and reformation of senates in a more conservative direction in Denmark (Skjæveland, this volume) and Sweden (Nilsson, this volume) in the 1860s. As the position of monarchs became less important over the nineteenth century and foreign powers stepped back, senates could - though not always along a linear path, as the case of Denmark shows - evolve in another, more conservative direction which came down to representing the interests of the elite (Verstegen, this volume). Colin Grittner (this volume) especially makes clear that, 
in the middle of the nineteenth century, the Canadian landed elite supported the idea of creating an elective upper chamber with high property qualifications for voters at the provincial level to safeguard their interests, though they did not succeed. In Sweden, these attempts were more successful (Nilsson, this volume), and in Denmark, a new Senate became a conservative bulwark in 1866, successfully dominating Danish politics until 1901 (Bijleveld \& Verstegen 2015). Nevertheless, as the cases of Belgium and Sweden illustrate, representing the interests of the elites did not necessarily mean that the senates blocked all changes. The Swedish upper house was quite progressive in an economic perspective (Nilsson, this volume), while Belgian senators saw it as their (conservative) duty to 'the people' to democratise (Beyen, this volume). In Finland however, the support for a house of second thought gradually faded as the confidence in 'the people' undermined the perceived necessity of a separate chamber, and the lack of foreign intervention during the Russian Revolution of 1905 gave Finns the room to decide not to install a senate.

By the twentieth century, parliamentarism and universal suffrage had been accepted, and 'the people' had become the true sovereign of the state; as such, senates started meeting new challenges. They had to reformulate their legitimacy; the claim that senates were 'representative bodies' came in for strong criticism, which becomes clear in the third part of this volume, titled Does a state still need a senate? An interesting case here is Ireland. After the First World War, strong foreign intervention led to the installation of a senate. Dorney (this volume) makes clear that British interference negatively influenced the legitimacy of the Irish Senate, which was considerably reformed from above in the 1930s. As we approach the twentieth century, we get closer to the existing literature on senates, in which legitimacy is a central issue. An interesting case here is Canada, where, according to Adam Coombs (this volume), after the First World War, attacking the existence of the Senate was an electoral strategy employed by the Prime Minister. In Ireland, the ruling party, Fianna Fáil, used the same argument in the 1930s (Dorney, this volume). Such opportunism is a forgotten aspect in the history of senates.

These events lead to the next question: why were senates abolished in some countries in the twentieth century but not in others? Some of them proved difficult to abolish for different reasons, as Meg Russell and Mark Sandford (2002) argued convincingly and as David E. Smith (this volume) illustrates for the Canadian case and Bert van den Braak (this volume) for that of the Netherlands. Senates have been criticised for having too little power or too much power, for being a carbon copy of the lower chamber, for not being democratic enough etc. (Russel \& Sandford 2002). In some cases, the critique resulted in their abolition, as Asbjørn Skjæveland (this volume) and Joakim Nergelius (this volume) discuss for Denmark and Sweden, respectively. From a Nordic perspective, the question of whether a state needs a senate can be answered with a clear 'no'. These countries have proven that stable democracies can easily do without a senate, but they still look for institutions that facilitate reflection and second thought and political representation of the people. In the Netherlands, Ireland and Canada, despite 
endless criticism, senates are still in 'full swing', with the Irish Senate surviving a referendum on its abolition in 2013 (MacCartheigh \& Martin, this volume). The Dutch Senate has succeeded in enhancing its power (Van den Braak, this volume) and the Canadian Senate has even managed to secure new roles (Cardinal, this volume). In Canada, the Senate has gained importance as an institute for ethnic and gender representation, while in Ireland, the Seanad was meant to represent religious and professional groups in society ( $\mathrm{O}^{\prime}$ Donoghue, this volume). This ability to reform themselves contests the broadly accepted notion that senates are inevitably on their way out. Some would even say that states need senates or at least need the room to reflect on legislation.

\section{Theory and history}

There is already extensive literature on bicameral systems, especially concerning the people's assemblies and the upper houses of major political powers. The digitisation of newspapers and the proceedings of upper houses and the availability of comparative data - as provided by the Inter-Parliamentary Union, for instance have led to a rise in the number of specialised books on senates, but it is widely accepted that the topic still needs more attention (Baldwin \& Shell 2001). More specifically, Schnatterer (2015), based on a database of more than 1,000 studies published from 1970 onwards, has noticed that academics are becoming more interested in senates, though this has mainly resulted in studies of senates in relation to the people's assemblies. Little research has, however, been conducted into their internal dynamics. Our study falls within a more recent trend, as perceived by Schnatterer and taking a more actor-centred approach. Still, in these studies, senates are not normally associated with political turmoil. On the contrary, they are considered to be perhaps the most stable element within any parliamentary system. This is probably the legacy of Montesquieu, being the darling of many theories about the balance of political forces within states. The fact that senates are supposed to stabilise a parliamentary system does not mean that they actually do so. The nineteenth-century examples of Denmark and Sweden make clear that senates can block necessary reforms while undermining their own legitimacy (Skjæveland, this volume; Nilsson, this volume). The crises we referred to in our conference 'Senates in Crises' are firstly those moments in history when the existence of senates was in jeopardy. Secondly and more frequently, these crises are moments of political upheaval, which saw the installation, prerogatives, workings and organisation of senates change. As the chapters by Bert van den Braak (this volume) about the Netherlands and by David E. Smith (this volume) about Canada make clear, these changes were not necessarily formal in nature. Senates can adapt and take on a different role without any constitutional change, which is the phenomenon that inspired the title of this volume.

Many studies focus on the legitimisation of senates. Blom (1992, p. 22) calls bicameralism a 'systematically inconvenient aspect of modern parliamentarism'. Authors offer a wide range of reasons for the justification of their endurance. Here, we see the idea echoed that bicameralism is a reflection of the past, if not 
an impediment for a genuinely democratic future. In this interpretation, a senate or an upper chamber is a historical successor of the estate of the nobility, which is incorrect. As Coakley has pointed out, the way estates functioned in historical times was much more complicated, and they were more than just a prelude to modern bicameralism. In addition, it is argued that the idea that the bicameral system in England was a model for other nations is a political myth, both in theory and in practice (Coakley 2014; Drexhage 2015; Haas 2010). The problem here is that when we take the British parliamentary system as the model of an early bicameral system, theoretical notions of bicameralism create a mythical history for senates that overlook the huge, innovative jump that was made in the Revolutionary Age. The emergence of senates is related to modern constitutional state-building - starting with the American Senate - and is not a remnant of pre-revolutionary times. The novelty of nineteenth- and early-twentieth-century senates is often overlooked (Haas 2010). As Drexhage (2015) rightly points out, 'the American Senate was the first example of a bicameral system that was not intended to represent different estates or social classes'.

Our volume deviates from the standard approach of investigating and analysing the present-day differences between senates in a selection of countries, treating the past as a prelude to the present. It is obvious that the literature on senates has focused greatly on the making of classifications and typologies, mostly elaborating further on the work of Arend Lijphart, in order to get a grip of the subject. However, we can agree with Blom that the subject is too amorphous to do so successfully, as all classifications differ according to the theoretical hypotheses scholars try to prove (cf. Blom 1992; Russell 2000; Haas 2010; Drexhage 2015). Interpreting bicameralism as a relic of the past explains why, on a more theoretical level, studies about senates often start by wondering why they have not yet disappeared altogether (Coakley 2014; Haas 2010; Bijleveld \& Verstegen 2019). On the contrary, as Nikolaj Bijleveld pointed out during a workshop in Amsterdam, recent decades show a revival of bicameralism in newly established (non-federal) democracies (cf. Coakley 2014).

Although the chapters presented here are written within the framework of nation states, they offer a wide range of insights about the history of senates. Of course, all the states considered here have their own peculiarities. Canada, for instance, until recently had far fewer inhabitants than the great powers in the Atlantic world and could therefore be considered a 'minor power', similar to the other nations covered here. Because of the country's growth from the middle of the nineteenth century onwards, however, as well as its sheer size and federal structure, the role of its Senate is different from what is found in minor powers in Europe. In general, a strong link can be noted between federalism and bicameralism (Drexhage 2015). Nevertheless, when comparing the function and the role of senates in federal and unitary states, this link becomes less relevant (Coakley 2014). The effectiveness of upper chambers in federations was recently discussed in Gamper (2018).

Much like Canada, Ireland was part of the British Commonwealth for a long time and has a traumatic history that cannot be seen elsewhere in the North 
Atlantic (MacCartheigh \& Martin, this volume). Other countries also have their own historic peculiarities: we have already mentioned the Belgian revolution of 1830 (Witte, this volume) and the Schleswig Wars between Germany and Denmark (Christiansen, this volume), which influenced the shaping of the upper houses. Senates tend to reflect nations' typical political cultures (Haas 2010) and the specific circumstances under which they were established and reformed. Furthermore, the way they were embedded in national political systems strongly influenced their possibility to adapt and reform, and this level of flexibility proved to be very important to senates since it could make the difference between either abolition or survival and even adaptation to new roles.

Though each state has a history of its own, comparisons between states are very useful as we do not just focus on how senates function within a national framework. We compare how senates, according to political reformers, should function and how they adapted or could adapt to new circumstances. The way reformers envisioned the roles of senates was influenced by what happened in neighbouring countries and reflected these issues and political problems. Senates changed both in crises and because of crises. Above all, reformers sought to (re-)invent senates in order to prevent the reocurrence of political crises, at home or elsewhere, or to adapt them to new political ideologies and practices.

Without aiming to endorse senates - as we know that states can do without them - we think our fascination with the subject is at least partly due to the fact that senates, as we know them now, were once a new phenomenon, part and parcel of the modern Western world, and managed to ride the high tide of democratic reforms.

\section{References}

Ajzenstat, J. et al. (eds.) (2003), Canada's Founding Debate (Toronto: University of Toronto Press).

Baldwin, N. and Shell, D. (2001), Second Chambers (London: Frank Cass).

Baturo, A. and Elgie, R (2018), 'why do authoritarian regimes adopt bicameralism cooptation, control, and masking controversial reforms', Democratization 25(5), pp. 919-937.

Bijleveld, N. and Verstegen, W. (2015), 'Adjusting the Horrors of Civil War. Reforming the Senate in Small Power Democracies in the Nationalistic Crises of the 1860s: Canada, Denmark and Sweden' [paper presented at Transatlantic Studies Association 14th Annual Conference]. Available at: www.rug.nl/staff/n.h.bijleveld/research/publications. html (accessed 23 March 2019).

Bijleveld, N. and Verstegen, W. (2019), 'Een Sourdine of een echte volksvertegenwoordiging? Memo over de senaat aan de Staatscommissie Bezinning Parlementair Stelsel'. Available at: www.rug.nl/staff/n.h.bijleveld/research (accessed 23 March 2019).

Blom, H.W. (1992), 'Bicameralism - history - theory - problems', in: Blom, H.W. (ed.), Bicameralisme: tweekamerstelsel vroeger en nu: handelingen van de Internationale Conferentie ter gelegenheid van het 175-jarig bestaan van de Eerste Kamer der StatenGeneraal in de Nederlanden (The Hague: Sdu), pp. 29-32.

Boyko, J. (2014), Blood and Daring. How Canada fought the American Civil War and Forged a Nation (Toronto: Vintage Canada). 
Coakley, J. (2014), 'The strange revival of bicameralism', Journal of Legislative Studies 20(4), pp. 542-572.

Drentje, J. (1998), Het vrijste volk der wereld. Thorbecke Nederland en Europa (Zwolle: Waanders).

Drentje, J. (2004), Thorbecke. Een filosoof in de politiek (Amsterdam: Boom).

Drexhage, B. (2015), Bicameral Legislatures. An International Comparison (The Hague: Ministry of the Interior and Kingdom Relations).

Ducharme, M. (2010), Le concept de liberté au Canada à l'époque des révolutions atlantiques 1776-1838 (Montreal: McGikk University Press).

Gamper, A. (ed.) (2018), Representing Regions, Challenging Bicameralism. Perspectives on Federalism. Special Issue 10(2).

Haas, C.M. (2010), 'Sein oder nicht sein: Bikameralismus und die Funktion Zweiter Kammern', in: Gisela Riescher et al. (eds.), Zweite Kammern (München: Oldenbourg Wissenschaftsverlag), pp. 3-18.

Israel, J. (2017), The Expanding Blaze. How the American Revolution Ignited the World, 1775-1848 (Princeton: Princeton University Press).

Laureys, V. et al. (eds.) (1995), De geschiedenis van de Belgische senaat (Tielt: Lannoo).

Palonen, K. (2019), Parliamentary Procedure, Rhetoric and Time (London: Palgrave MacMillan).

Riescher, G. et al. (eds.) (2010), Zweite Kammern (München: Oldenbourg Wissen schaftsverlag).

Russell, M. (2000), Reforming the House of Lords (Oxford: Oxford University Press).

Russell, M., Sandford M. (2002), 'Why are Second Chambers so Difficult to Reform', The Journal of Legislative Studies. 8(3), pp. 79-89.

Schnatterer, T. (2015), 'Understudied and underestimated? What determines scientific attention on second chambers?', French Politics 13(3), pp. 302-317.

Stengers, J. (1995), 'De grondwet van 1831: theorie en praktijk', in: Laureys, V. et al. (eds.), De geschiedenis van de Belgische senaat (Tielt: Lannoo), pp. 31-42. 